\begin{tabular}{cc|c}
\hline & $\begin{array}{c}\text { Tarım Bilimleri Dergisi } \\
\text { Tar. Bil.Der. }\end{array}$ & Journal of Agricultural Sciences \\
& $\begin{array}{c}\text { Dergi web sayfası: } \\
\text { www.agri.ankara.edu.tr/dergi }\end{array}$ & $\begin{array}{c}\text { Journal homepage: } \\
\text { www.agri.ankara.edu.tr/journal }\end{array}$ \\
\hline
\end{tabular}

\title{
Soil Particle Size Distribution and Solid Fractal Dimension as Influenced by Pretreatments
}

\author{
Hikmet GUNAL $^{\mathrm{a}}$, Sabit ERSAHIN ${ }^{\mathrm{b}}$, Buket Y. UZ ${ }^{\mathrm{c}}$, Mesut BUDAK ${ }^{\mathrm{d}}$, Nurullah ACIR ${ }^{\mathrm{a}}$ \\ ${ }^{a}$ Gaziosmanpasa University, Faculty of Agriculture, Department of Soil Science and Plant Nutrition, 60240, Tokat, TURKEY \\ ${ }^{b}$ Karatekin University, Faculty of Forestry, Department of Soil Science and Ecology, Cankiri, TURKEY \\ ${ }^{c}$ Akdeniz University, Faculty of Agriculture, Antalya, TURKEY \\ ${ }^{d}$ Hakkari University, Junior Technical College, Department of Horticulture, Hakkari, TURKEY
}

\section{ARTICLE INFO}

Research Article — Agricultural Technologies DOI: 10.1501/Tarimbil_0000001173

Corresponding author: Hikmet GUNAL, e-mail: hikmet.gunal@gop.edu.tr, Tel: +90(356) 252 16 16/2177

Received: 26 June 2011, Received in revised form: 15 December 2011, Accepted: 28 December 2011

\begin{abstract}
Soil particle-size distributions can provide valuable information on the processes and products of soil formation. The purpose of this study was to assess the pretreatment effect on the particle size distribution and corresponding fractal dimension of particle size $\left(D_{\mathrm{s}}\right)$. Twenty nine soil samples were collected from diverse climatic and pedogenic conditions with diverse particle size distributions, calcium carbonate and organic matter contents. To evaluate the effect of pretreatment on soil particle-size distribution, four different types of particle size distributions and fractal dimension values were obtained. Treatments included, 1) no pretreated, 2) organic matter removed with $\left.\mathrm{H}_{2} \mathrm{O}_{2}, 3\right)$ calcite $\left(\mathrm{CaCO}_{3}\right)$ removed with $\mathrm{NaOAc}$, and 4) organic matter and calcium carbonate removed. Clay content ranged from 12.5 to $66.5 \%$, organic matter varied from 0.05 to $4.25 \%$, and calcium carbonate content ranged from 5.57 to $60.09 \%$. The difference in clay content before $(42.36 \%)$ and after $(44.61 \%)$ pretreatment of organic matter was significant $(P<0.05)$ but the same pretreatment didn't yield any significant differences in sand, silt and fractals. However, fractal and sand content obtained after calcium carbonate removal were significantly different from those of non-pretreated samples $(P<0.01$ and $P<0.05$, respectively). Dissolving calcium carbonate probably removed the clay sized calcium carbonate particles which were considered within the clay fraction. Therefore, the lowest mean fractal values $\left(\mathrm{Ds}_{\mathrm{c}}=2.8343\right.$ and $\left.\mathrm{Ds}_{\mathrm{oc}}=2.8336\right)$ were obtained after calcium carbonate removal. The study results revealed that pretreatments affected the rates of particle size distributions. However, the differences in clay, silt, and sand contents obtained when pretreated together with $\mathrm{H}_{2} \mathrm{O}_{2}$ and $\mathrm{NaOAc}$ were not significantly different.
\end{abstract}

Keywords: Organic matter; Calcium carbonate; Pretreatment; Soil texture; Fractal dimension

\section{Ön Muameleden Etkilenen Toprak Parçacık Büyüklük Dağılımı ve Katı Fraktal Boyutları}

\section{ESER BİLGISI}

Araştırma Makalesi — Tarım Teknolojileri

Sorumlu Yazar: Hikmet GUNAL, e-posta: hikmet.gunal@gop.edu.tr, Tel: +90(356) 252 16 16/2177

Geliş tarihi: 26 Haziran 2011, Düzeltmelerin gelişi: 15 Aralık 2011, Kabul: 28 Aralık 2011 


\section{ÖZET}

Toprak parçacık büyüklük dağılımı toprak oluş işlemleri ve ürünleri hakkında önemli bilgiler sağlamaktadır. Bu çalışmanın amacı, ön muamelenin parçacık büyüklük dağılımına ve buna karşılık gelen parçacıkların fraktal boyuna (Ds) etkisini belirlemektir. Farklı iklim ve toprak oluşum işlemleri altında bulunan ve parçacık büyüklük dağılımı, kalsiyum karbonat ve organik madde içerikleri değişken olan yirmi dokuz toprak örneği toplanmıştır. Ön muamelenin parçacık büyüklük dağılımına etkisini değerlendirmek için, dört farklı şekilde parçacık büyüklük dağılımı ve fraktal boyut değerleri elde edilmiştir. Uygulamalar 1)kontrol (muamele yapılmayan), 2) $\mathrm{H}_{2} \mathrm{O}_{2}$ ile organik maddenin uzaklaştırılması 3) kalsit'in $\left(\mathrm{CaCO}_{3}\right)$ NaOAc ile uzaklaştırılması ve 4) organik madde ve kalsiyum karbonatın uzaklaştırılması şeklindedir. Örneklerin kil içeriği \%12.5 ile \%66.5, organik madde \%0.05 ile $\% 4.25$ ve kalsiyum karbonat içeriği \%5.57 ile \%60.09 arasında değişmektedir. Organik madde uzaklaştırılmadan önce ve sonraki kil içeriği istatistiksel olarak önemli $(P<0.05)$ iken bu fark silt ve kum içeriği için ve fraktal değerleri için önemli bulunmamıştır. Bununla birlikte, kalsiyum karbonat uzaklaştırılan örneklerin fraktal değerleri ve kum içeriği muamele yapılmayan örneklere göre önemli düzeyde farklı bulunmuştur (sırası ile $P<0.01$ ve $P<0.05$ ). Kalsiyum karbonatın uzaklaştırılması muhtemelen kil fraksiyonu içinde görülen kil büyüklügündeki kalsiyum karbonatın uzaklaştırmıştır. Bundan dolayı, en düşük ortalama fraktal değerleri $\left(\mathrm{Ds}_{\mathrm{c}}=2.8343\right.$ ve $\mathrm{Ds}_{\mathrm{oc}}=2.8336$ ) kalsiyum karbonat uzaklaştırılması ile bulunmuştur. Çalışma sonuçları ön muamelelerin parçacık büyüklük dağılımını etkilediğini göstermiştir. Bununla birlikte, hem $\mathrm{H}_{2} \mathrm{O}_{2}$ hem de $\mathrm{NaOAc}$ ile muamele edildiğinde kil, silt ve kum içeriklerindeki farklılık önemli olmamıştır.

Anahtar sözcükler: Organik madde; Kalsiyum karbonat; Ön muamele; Toprak tekstürü; Fraktal boyutu

(C) Ankara Üniversitesi Ziraat Fakültesi

\section{Introduction}

Primary minerals originate from weathering of a parent material, and generally present in the sandand silt-sized fractions, while secondary minerals such as clay minerals are the result of formation of new minerals (Wu et al 1993; Posadas et al 2001). Particle-size distributions of soils are often used to estimate other soil properties such as soil moisture characteristics and hydraulic conductivity (Bittelli et al 1999; Khodaverdiloo et al 2011), thus accurate estimation of soil properties strongly depends on the accuracy of particle size determination.

The physical and chemical behaviors of soils are significantly influenced by particle-size distribution which is important for soil interpretations, determination of soil hydrologic qualities, plant nutrient requirements and classifications (Eshel et al 2004). Particle size distribution reflects the relative balance of weathering and pedogenetic processes, and it is typically presented as percentage of the total mass of soil by a given size fraction (Eshel et al 2004). The textural triangle provided a common language with scientists, agronomists and engineers describes the major physical property of a soil (Filgueira 2006).

Conventional particle-size analysis methods involve measurement of the mass fractions of clay, silt, and sand. These fractions are used to find the textural class using a textural diagram, commonly in form of a textural triangle (Gee \& Bauder 1986; Soil Survey Division Staff 1993). Standard analyses of dry soils usually include dispersion of the soils followed by particle size determination by a variety of time consuming methods. Clay and silt particles are usually measured with sedimentation using a hydrometer or pipette method. Sand is then measured with sieving which is the process whereby the soil is separated in particle size classes using different sizes of sieves. Sedimentation is the process of the settling of soil particles in a liquid. The difference in settling rate enables the particle size classes to be separated.

Soil particles ranging from 0 to $2 \mathrm{~mm}$ may contain separate sand, silt, and clay particles as well soil aggregates (Stanchi et al 2008). Sand, silt, and clay particles are often sticked together with cementing agents such as sparingly soluble salts (calcium carbonate, gypsum and etc) and organic compounds. The sticked or bonded 
particles form large soil structural units, i.e. aggregates and peds. Various treatments are used to break the bonds between primary soil particles and soil aggregates prior to particle size distribution measurement. Treatments lead to the fragmentation of soil material (Stanchi et al 2006). The destruction of coarse sand-size aggregates releases not only the clay particles, but also fine sand and silt (Bronick \& Lal 2005).

Pretreatment in particle size determination enhances the dispersion of aggregates. Therefore, it is a key step in particle size determinations, and is generally recommended. Physical treatments are used to enhance the dispersion of soils while chemical treatments (organic matter and calcium carbonate removal) are used to remove carbonates and organic matter coatings (Gee \& Bauder 1986). Soil organic matter (SOM) and calcium carbonate constrains the dispersion of soil colloids. Highly aggregated clay soils may behave like coarse sand in terms of water movement. Therefore, removing organic matter and soluble salts is recommended prior to particle size analysis (Gee \& Bauder 1986) and is also used before characterization of soil mineralogy (Feller et al 1992). Chemical treatments of soil result in removal of coating found between soil particles (Gee \& Bauder 1986). The outcome of such measurements may closely depend on the effectiveness of the treatment which is particularly important in particle size distributions of fine soil fractions, as SOM and calcium carbonate are known strong binding agents (Tisdall 1996). The absence of pretreatment for SOM could in some cases affect the dispersion of particles leading to incomplete segregation, and therefore to an underestimation of small particle fractions (Bittelli et al 1999). The SOM resistant to $\mathrm{H}_{2} \mathrm{O}_{2}$ treatment is considered to be stabilized in organomineral associations. Leifeld \& Kögel-Knabner, (2003) reported that particles $<1 \mu \mathrm{m}$ were only mechanically dispersed indicating that smaller particles are bound more strongly, forming clay clusters and silt-sized micro-aggregates.

The presence of gypsum in soils affects their physical properties greatly and affects particle- size analysis. Comparison of field and laboratory determinations of the texture of gypsiferous soils can be misleading because gypsum occurs as crystals in the various size fractions. Consequently field textures are normally coarser than laboratory determinations (Hesse 1976). The calcium carbonate in soil is made up almost entirely of tiny calcite crystals which dominate the clay-sized fraction, yet they do not have the same characteristics in terms of water retention as typical phyllo-silicate clays minerals. Calcium carbonate in soil results in feeling siltier when hand-texturing than it might actually be. The pipette and hydrometer methods use an average value for the particle density in determining settling times of particles. Dispersing the soil for the pipette or hydrometer methods can result in the break-up of calcium carbonate fragments into smaller calcite crystals making the soil appear more clayey in texture than it is (Kerry \& Oliver 2006). Therefore the purpose of this study was to assess the pretreatment effect on the particle size distribution of twenty nine soil samples collected from diverse climatic and pedogenic conditions with diverse particle size distributions and calcium carbonate and organic matter contents.

One of the latest developments in the study of soil particle size distributions has focused on the use of fractal mathematics to characterize particle sizes (Bitelli et al 1999; Tyler \& Wheatcraft 1992). The fractal concept has increasingly been used to characterize soil properties. The model of fractal fragmentation is a possible method to describe observed particle-size distributions with a minimum set of parameters (Tyler \& Wheatcraft 1992). Perfect \& Kay (1991) used fractal to evaluate the influence of tillage on soil aggregation, and Ersahin et al (2006) estimated specific surface area and soil cation exchange capacity using their solid fractal dimensions. The application of fractal geometry to describe soil degradation and dynamics is also becoming a useful tool for better understanding of the performance of soil systems (Jin et al 2011).

In the present work, it was compared soil particle size distributions and fractals before and 
after removing organic matter, calcium carbonate, and combination of both.

\section{Materials and Methods}

\subsection{Soils}

In this study, 29 soil samples from different horizons were used to represent a wide variety of parent materials, weathering conditions, organic matter contents, calcium carbonate contents and particle size distributions (textures). Soil samples were air dried, gently crushed, and passed through a 2-mm sieve to exclude fractions $>2 \mathrm{~mm}$.

\subsection{Pretreatments and analyses}

Calcium carbonate contents were determined using cold $1 \mathrm{M} \mathrm{HCl}$. Since all soils contained carbonates, the samples were treated with $0.5 \mathrm{M}$ sodium acetate at $75^{\circ} \mathrm{C}$ for at least $1 \mathrm{~h}$. After acetate treatment, samples were washed with deionized water. Soil organic matter was determined with the Walkley-Black method (Nelson \& Sommers, 1982), and ranged from 0.05 to $7.35 \%$ by weight. All soil samples were further pretreated by removing organic matter using $\mathrm{H}_{2} \mathrm{O}_{2}$ $(30 \%, \mathrm{w} / \mathrm{w})($ Gee \& Bauder 1986). Briefly, $40 \mathrm{~g}$ of sample was treated with $\mathrm{H}_{2} \mathrm{O}_{2}$ initially at room temperature. After gas development ceased to evolve, suspensions were boiled at $80^{\circ} \mathrm{C}$ for $24 \mathrm{~h}$, respectively. Increasing temperature accelerates the decomposition of $\mathrm{H}_{2} \mathrm{O}_{2}$ but shortens the reaction time necessary to oxidize organic matter (Schultz et al 1999).

After pretreatments, all soil samples were dispersed with sodium hexametaphosphate. Samples then were soaked for an overnight and transferred to a dispersing cup and mixed for 5 minutes with an electric mixer. The suspension was poured into a sedimentation cylinder and distilled water was added to bring the volume $1000 \mathrm{ml}$. Afterward, the suspension was shaken for $1 \mathrm{~min}$. The hydrometer was then lowered into the suspension and the readings were taken after $40 \mathrm{~s}$ and $2,8,15,30,60,120,240$ and $1440 \mathrm{~min}$. Also the temperature was recorded at each time to allow viscosity and density corrections (Gee \& Bauder 1986; Filgueira et al 2003). Soil solutions were sieved with the sodium hexametaphosphate solution at $2000,1180,1000,850,425,355,212$, and $75 \mu \mathrm{m}$ mesh filters to determine sand fractions. Particles, smaller than $75 \mu \mathrm{m}$, were analyzed by the hydrometer method.

\subsection{Calculation of fractal dimensions of particle size distributions}

In our study, experimental data obtained from particle-size analyses were used along with Equation 1 to estimate fractal dimension of particle-size distribution, $\mathrm{D}_{\mathrm{s}} . \quad \mathrm{M} \quad(\mathrm{r}<\mathrm{R})$ was obtained as the cumulative mass of the particles smaller than the given particle size (R) in the sample from hydrometer or sieve analyses as described by Gee \& Bauder (1986). To evaluate $\mathrm{D}_{\mathrm{s}}$ in Equation 1, we regressed $\log \left(\mathrm{M}(\mathrm{r}<\mathrm{R}) / \mathrm{M}_{\mathrm{T}}\right)$ against $\log \left(\mathrm{R} / \mathrm{R}_{\text {upper }}\right)$ for each soil sample. Then the $D_{s}$ values were calculated from the slope of resulting regression equations (Tyler \& Wheatcraft, 1992);

$$
\frac{M(r<R)}{M_{T}}=\left(\frac{R}{R_{\text {Lupper }}}\right)^{3-D s} \text {, }
$$

where, $M(g)$ is the mass of soil particles with a radius smaller than $R(r<R), R_{L u p p e r}$ is the upper size limit for the fractal behavior, $\mathrm{M}_{\mathrm{T}}$ is the total mass (g) of the soil lower than $R_{L u p p e r}$, and $D_{s}$ is the solid fractal dimension.

\subsection{Data analyses}

Descriptive statistics mean, range, standard deviation, coefficient of variation (CV), skewness and kurtosis for soil characteristics evaluated were calculated. Measured values (dependent variable) for clay content were regressed against each of the variables, and then $D_{s}$ values were calculated for different pretreatments. Depending on the nature of the relationship, linear or polynomial regression was considered. Coefficient of determination $\left(R^{2}\right)$, mean squared error and significance of overall regression $(P)$ were considered in the evaluating the validity of regression equations to describe variation in dependent variables (Kleinbaum et al 1988). The statistical analysis were performed using the software SPSS (Version 13.0). 


\section{Results and Discussions}

Organic matter removal with hydrogen peroxide and calcium carbonate dissolution with sodium acetate methods were used in this study to evaluate the effectiveness of the pretreatments on the analysis of particle-size, and complementary fractal coefficients were calculated which are highly affected by clay content of the soils.

\subsection{Soil characteristics}

The soils investigated were differing in pedogenesis (Entisols, Inceptisols, Mollisols, Alfisols and Vertisols), and soil calcium carbonate content ranged from $5.57 \%$ to $60.09 \%$, while organic matter content ranged from 0.05 to $4.25 \%$ (Table 1). Since the major soil binding components are organic matter and calcium carbonate, soils investigated were representing a wide range of these binding elements. Descriptive statistics of soil particle size distributions before and after pretreatments were presented in Table 2 . The soil samples were also particularly chosen to represent a wide range of particle size distribution (Figure 1) to evaluate the effects of each pretreatment on different textural groups. Comparing dispersion among different soil properties, it is convenient and appropriate to express variance free from units of measurements. Coefficient of variation (CV) which is the ratio of standard deviation to the mean is useful and meaningful index to compare the variability

Table 1-Texture, organic matter and calcium carbonate contents of soils Çizelge 1-Toprakların tekstür, organik madde ve kalsiyum karbonat içerikleri

\begin{tabular}{|c|c|c|c|c|c|c|c|}
\hline $\mathrm{No}$ & Horizon & $\mathrm{CaCO}_{3}, \%$ & Organic matter, $\%$ & Sand, \% & Clay, \% & Silt, \% & Texture class \\
\hline 1 & $2 \mathrm{Ctk}$ & 6.31 & 0.05 & 44.5 & 30.9 & 24.7 & Clay Loam \\
\hline 2 & $3 \mathrm{Btk}_{1}$ & 19.47 & 0.08 & 6.5 & 65.1 & 28.5 & Clay \\
\hline 3 & $\mathrm{Ck}$ & 17.0 & 0.14 & 57.3 & 23.2 & 19.5 & Sandy Clay Loam \\
\hline 4 & $\mathrm{C}_{2}$ & 12.0 & 0.16 & 53.9 & 22.6 & 23.5 & Sandy Clay Loam \\
\hline 5 & $\mathrm{Ck}_{1}$ & 18.0 & 0.18 & 65.4 & 19.5 & 15.1 & Sandy Loam \\
\hline 6 & $\mathrm{C}_{1}$ & 21.5 & 0.18 & 33.6 & 38.2 & 28.3 & Clay Loam \\
\hline 7 & $\mathrm{C}_{1}$ & 11.0 & 0.24 & 53.4 & 22.5 & 24.1 & Sandy Clay Loam \\
\hline 8 & $\mathrm{Ck}$ & 18.55 & 0.25 & 25.6 & 43.5 & 30.8 & Clay \\
\hline 9 & $2 \mathrm{Ctk}$ & 5.57 & 0.26 & 47.5 & 32.6 & 19.8 & Sandy Clay Loam \\
\hline 10 & $2 \mathrm{Btk}_{1}$ & 34.98 & 0.30 & 18.9 & 66.5 & 14.6 & Clay \\
\hline 11 & $2 \mathrm{Ctk}_{1}$ & 17.43 & 0.40 & 24.9 & 40.2 & 34.9 & Clay Loam \\
\hline 12 & Bwk & 13.72 & 0.52 & 24.4 & 44.2 & 31.4 & Clay \\
\hline 13 & $\mathrm{Bw}_{2}$ & 60.09 & 0.57 & 43.2 & 32.4 & 24.4 & Clay Loam \\
\hline 14 & $\mathrm{Bw}_{1}$ & 54.16 & 0.79 & 38.9 & 32.3 & 28.8 & Clay Loam \\
\hline 15 & $\mathrm{C}_{1}$ & 13.3 & 0.85 & 2.4 & 43.1 & 54.5 & Slaty Clay \\
\hline 16 & $\mathrm{Ap}$ & 6.33 & 0.89 & 31.1 & 25.0 & 43.9 & Clay \\
\hline 17 & Ap & 5.59 & 0.90 & 63.7 & 12.5 & 23.8 & Sandy Loam \\
\hline 18 & $\mathrm{Bw}_{2}$ & 16.4 & 1.54 & 12.1 & 58 & 29.9 & Clay \\
\hline 19 & Ap & 6.02 & 1.57 & 65.9 & 17.9 & 16.2 & Sandy Loam \\
\hline 20 & $\mathrm{Ap}$ & 9.63 & 1.85 & 18.7 & 61.2 & 20.1 & Clay \\
\hline 21 & $\mathrm{~A}$ & 19.85 & 2.04 & 20.1 & 51.7 & 28.2 & Clay \\
\hline 22 & $\mathrm{Bw}_{1}$ & 16.3 & 2.04 & 13.9 & 60.3 & 25.9 & Clay \\
\hline 23 & A & 21.14 & 2.06 & 18.2 & 52.2 & 29.5 & Clay \\
\hline 24 & $\mathrm{Bt}_{1}$ & 18.0 & 2.10 & 13.7 & 65.5 & 20.8 & Clay \\
\hline 25 & Ap & 11.34 & 2.11 & 15.1 & 46.3 & 38.6 & Clay \\
\hline 26 & $\mathrm{~A}$ & 17.81 & 2.23 & 19.1 & 51.0 & 29.9 & Clay \\
\hline 27 & Ap & 9.11 & 2.42 & 11.3 & 42.5 & 46.2 & Silty Clay \\
\hline 28 & $\mathrm{~A}$ & 18.5 & 3.99 & 13.4 & 57.4 & 29.2 & Clay \\
\hline 29 & Ap & 14.9 & 4.25 & 14.2 & 60.5 & 25.3 & Clay \\
\hline
\end{tabular}


Table 2-Descriptive statistics of soil particle size distributions before and after pretreatments ${ }^{1}(\mathbf{N}=\mathbf{2 9})$ Çizelge 2-Ön muamele öncesi ve sonrasında parçacık büyüklük dağllımlarının tanımlayıcı istatistikleri

\begin{tabular}{lcccccc}
\hline & Minimum & Maximum & Mean & Std. Deviation & Variance & Skewness \\
\hline Sand-NP & 2.4 & 65.9 & 29.64 & 18.94 & 358.66 & 0.67 \\
\hline Sand-O & 1.67 & 73.8 & 28.89 & 23.03 & 530.17 & 0.71 \\
\hline Sand-C & 3.36 & 78.52 & 32.87 & 23.57 & 555.42 & 0.613 \\
\hline Sand-OC & 5.01 & 77.53 & 31.46 & 23.75 & 564.28 & 0.698 \\
\hline Silt-NP & 14.6 & 54.5 & 28.01 & 8.92 & 79.6 & 1.126 \\
\hline Silt-O & 4.01 & 53.47 & 26.54 & 12.79 & 163.57 & 0.246 \\
\hline Silt-C & 2.73 & 56.42 & 25.53 & 12.61 & 159.05 & 0.296 \\
\hline Silt-OC & 3.86 & 60.27 & 26.99 & 12.59 & 158.55 & 0.636 \\
\hline Clay-NP & 12.5 & 66.5 & 42.36 & 15.97 & 255.15 & -0.166 \\
\hline Clay-O & 15.15 & 71.83 & 44.61 & 18.27 & 333.97 & 0.071 \\
\hline Clay-C & 10.61 & 88.18 & 41.59 & 21.03 & 442.17 & 0.403 \\
\hline Clay-OC & 12.7 & 69.9 & 41.55 & 18.76 & 351.97 & -0.01 \\
\hline
\end{tabular}

${ }^{1} \mathrm{NP}$; no-pretreatment, $\mathrm{O}$; removal of organic matter, $\mathrm{C}$; removal of $\mathrm{CaCO}_{3}, \mathrm{OC}$; removal of organic matter and $\mathrm{CaCO}_{3}$

(Wilding and Dress 1983). Wilding and Dress (1983) indicated that $\mathrm{CV} \leq 15 \%$ is accepted as the least variability, $\mathrm{CV}$ between $16-35 \%$ is considered moderate variability and $\mathrm{CV}$ greater than $35 \%$ is reported as high variability. The CV of sand, clay, organic matter and calcium carbonates were over $35 \%$ which belonged to the strong degree of variability (Table 2).

This study results indicated that particle size distributions with removing calcium carbonate (C), organic matter (O) and both calcium carbonate and organic matter (CO) differed from those obtained by textural analysis without any pretreatment (NP) (Table 2 and Figure 1). Coefficients of variation for all textural components were increased with pretreatments. The greatest CV value for silt (from $31.85 \%$ with NP to $49.39 \%$ ) and clay contents (from $37.70 \%$ with NP to 50.57\%) were obtained after carbonates removal and, the highest $\mathrm{CV}$ for sand content (from $63.90 \%$ with NP to $79.72 \%$ ) was occurred with the removal of organic matter.

The relationships between clay contents and the fractals calculated for different pretreatments were also investigated to understand the effect of organic matter removal and calcium carbonate dissolution on the solid fractal dimension of soils (Figure 2). A second degree polynomial relationship was occurred between clay content and $D_{s}$ values. Fractal behavior of clay size particles deteriorated with the pretreatments applied and the highest relationship obtained with the regression of $D_{s}$ versus non pretreated clay content in which equation explained $97.6 \%$ of the variation in clay content (Figure 2). $D_{s}$ values sharply increased with initial clay content increase and, the further increase in clay content resulted in smaller increases in $\mathrm{D}_{\mathrm{s}}$ values. In general, greater values of $\mathrm{D}_{\mathrm{s}}$ are associated with finer textures and smaller values are connected with coarser textures (Ersahin et al 2006). The fractal dimension values increased with clay content, and the effect of pretreatment is probably related to the removal of cementing materials between individual particles.

The values of $D_{s}$ together with their corresponding coefficient of determinations $\left(\mathrm{R}_{\mathrm{Ds}}^{2}\right)$ for treated and untreated soil samples were presented in Table 3. The $\mathrm{D}_{\mathrm{s}}$ values for untreated samples ranged from 2.6834 to $2.9311, \mathrm{D}_{\mathrm{so}}$ from 2.7128 to $2.9276, \mathrm{D}_{\text {sc }}$ from 2.6930 to 2.9694 and $\mathrm{D}_{\text {soc }}$ from 2.6465 to 2.9208 .

\subsection{Effect of organic matter}

Particle-size distribution measurements are strongly influenced by the experimental methods of dispersion of the soil particles. The dispersion itself can be regarded as a fragmentation process. Organic matter increases aggregate stability and hence leads to less fragmentation (Rasiah et al 1993). Therefore, organic matter removal in soils probably leads to an increase in the numbers of 

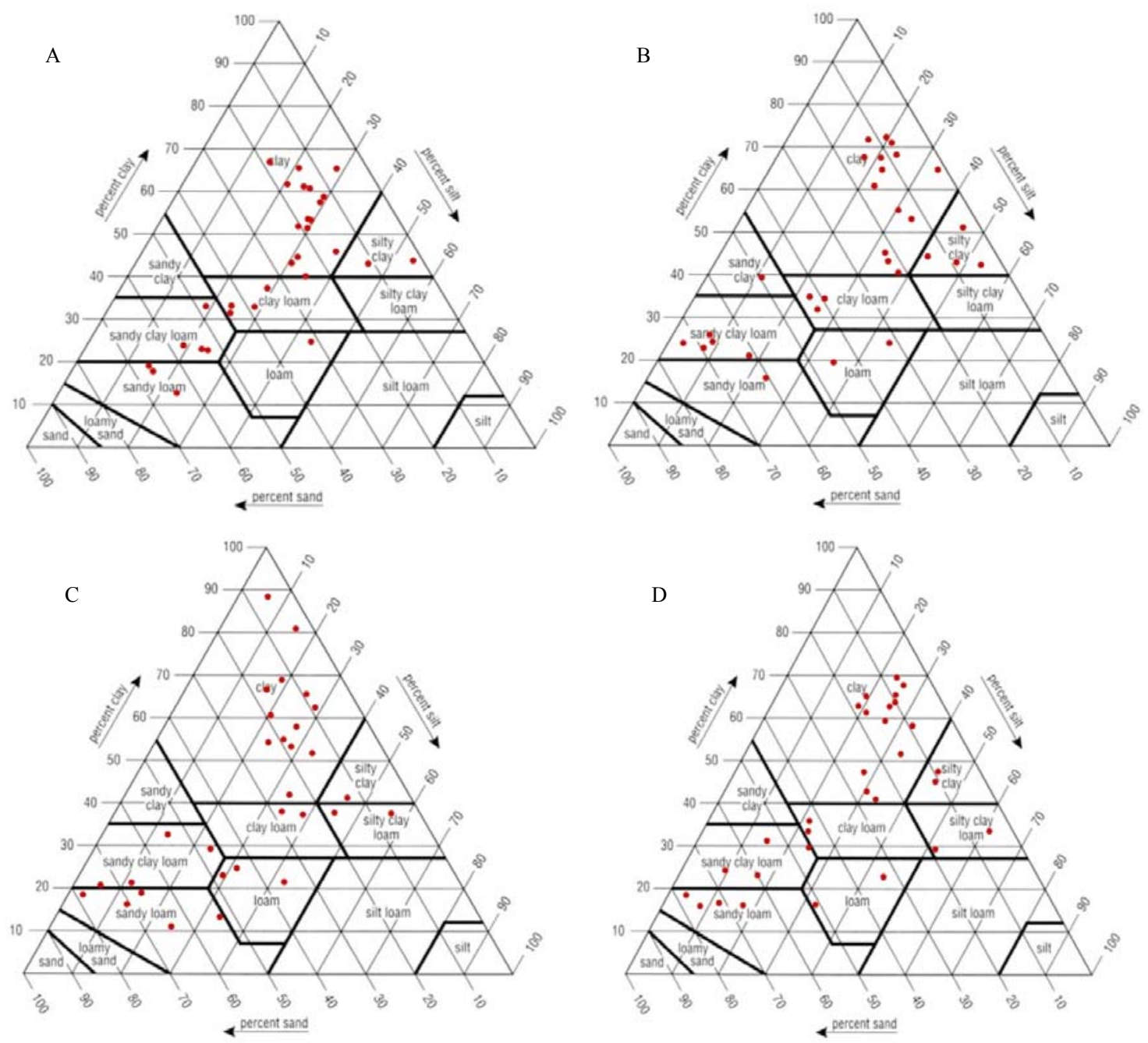

Figure 1-Distribution of soils studied within texture triangle before and after pretreatments. A: No pretreatment B: Organic matter removal C: Calcium carbonate removal D: Organic matter and Calcium carbonate removal

Şekil 1-Ön muameleler öncesi ve sonrasında toprakların tekstür üçgeni içersindeki dağılımı. A: Ön muamele yapılmadı B: Organik madde uzaklaştırması C: Kalsiyum karbonat uzaklaştırması D: Organik madde ve kalsiyum karbonat uzaklaştırması

smaller particles. The highest mean clay content $(44.6 \%)$ was obtained with organic matter removal (Table 2 and Figure 1). The slight increase in coarse clay fraction was also reported by Stanchi et al (2008) who investigated the break-up of aggregates $<2 \mathrm{~mm}$ after applying five different chemical and physical agents.

The paired t-tests of particle size distributions and fractal dimensions revealed that values of fractals obtained after organic matter removal 

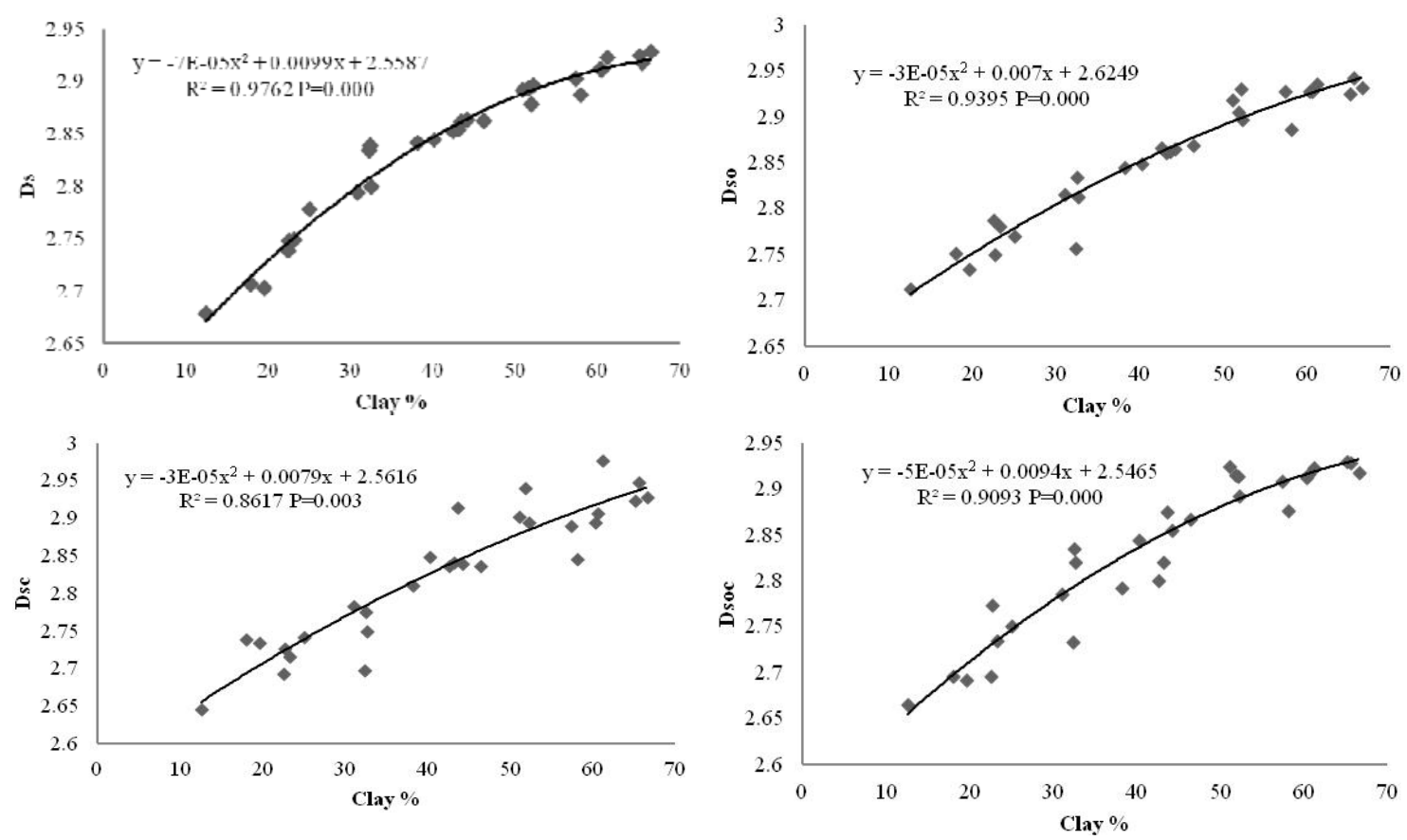

Figure 2-Relationship between clay content and fractal dimensions for non treated, organic matter removed, calcium carbonate removed and both calcium carbonate and organic matter removed samples

Şekil 2-Muamele edilmemiş, organik madde uzaklaştırılmış, kalsiyum karbonat uzaklaştırılmış ve hem kalsiyum karbonat hem de organik madde uzaklaştırılmış örneklerin kil içerikleri ve fraktal boyutları arasindaki ilişki

$\left(D_{\text {so }}\right)$ were significantly different from $(P<0.05)$ fractals obtained after calcium carbonate removal $\left(D_{\text {sc }}\right)$ and organic matter plus calcium carbonate removal $\left(\mathrm{D}_{\mathrm{soc}}\right)(P<0.01)$. However, the mean difference of Ds in removal of organic matter plus calcium carbonate was closer to that of organic matter removal than mean difference of calcium carbonate removal alone (Table 4). The results indicated better fragmentation of soil aggregates after destruction of soil organic binding components with hydrogen peroxide.

The difference in clay content before and after organic matter removal was significant $(P<0.05)$, whereas the other particle size characteristics were not significantly changed. The difference in clay content probably resulted from destruction of some of the sand and silt size aggregates. The sand-sized aggregates remaining after dispersion with sodium hexametaphosphate results in overestimation of sand content in sedimentation analysis. Schmidt et al (1999) indicated that the diameter of lignite particles, remaining even after oxidation with hydrogen peroxide, is overestimated the sand content by a factor of 1.66. Therefore, they recommended ultrasonication to disrupt sand-sized lignite particles to finer particle size fractions.

The relationship between clay content and fractal dimension calculated after removing organic matter was explained with a second degree polynomial regression, and was the equation obtained described $93 \%$ of the variation in clay content.

\subsection{Effect of calcium carbonate}

The particle size distribution and the fractals 
Table 3-Fractal dimensions (Ds) ${ }^{1}$ of particle size distributions obtained for different pretreatments, coefficient of determinations, calcium carbonate and organic matter contents of soils

Çizelge 3-Farklı ön muamelelerde elde edilen parçacık büyüklük dağılımlarına ait fraktal boyutlar (Ds), belirleme katsayıları, toprakların kalsiyum karbonat ve organik madde içerikleri

\begin{tabular}{|c|c|c|c|c|c|c|c|c|c|}
\hline $\mathrm{No}$ & Horizon & $D s$ & Dso & $D s c$ & Dsoc & $R^{2}$ & $R^{2} O$ & $R^{2} c$ & $R^{2} O C$ \\
\hline 1 & $2 \mathrm{Ctk}$ & 2.8114 & 2.8235 & 2.8006 & 2.7984 & 0.96 & 0.95 & 0.94 & 0.94 \\
\hline 2 & $3 \mathrm{Btk}_{1}$ & 2.9252 & 2.9072 & 2.9202 & 2.9202 & 0.76 & 0.6 & 0.83 & 0.71 \\
\hline 3 & $\mathrm{Ck}$ & 2.7909 & 2.8237 & 2.7589 & 2.7773 & 0.92 & 0.80 & 0.88 & 0.90 \\
\hline 4 & $\mathrm{C}_{2}$ & 2.7814 & 2.8022 & 2.7783 & 2.8068 & 0.97 & 0.84 & 0.89 & 0.94 \\
\hline 5 & $\mathrm{Ck}_{1}$ & 2.8485 & 2.8721 & 2.8418 & 2.8244 & 0.97 & 0.91 & 0.93 & 0.93 \\
\hline 6 & $\mathrm{C}_{1}$ & 2.7693 & 2.7872 & 2.7886 & 2.7585 & 0.77 & 0.85 & 0.85 & 0.85 \\
\hline 7 & $\mathrm{C}_{1}$ & 2.7671 & 2.827 & 2.7477 & 2.7565 & 0.95 & 0.89 & 0.91 & 0.87 \\
\hline 8 & $\mathrm{Ck}$ & 2.8641 & 2.8398 & 2.9014 & 2.8648 & 0.89 & 0.74 & 0.79 & 0.85 \\
\hline 9 & $2 \mathrm{Ctk}$ & 2.8967 & 2.8282 & 2.7596 & 2.8434 & 0.80 & 0.98 & 0.90 & 0.97 \\
\hline 10 & $2 \mathrm{Btk}_{1}$ & 2.9311 & 2.9225 & 2.9235 & 2.9117 & 0.88 & 0.72 & 0.77 & 0.80 \\
\hline 11 & $2 \mathrm{Ctk}_{1}$ & 2.8571 & 2.8428 & 2.8499 & 2.8454 & 0.94 & 0.87 & 0.90 & 0.89 \\
\hline 12 & Bwk & 2.8753 & 2.8647 & 2.8461 & 2.8612 & 0.96 & 0.90 & 0.94 & 0.95 \\
\hline 13 & $\mathrm{Bw}_{2}$ & 2.8381 & 2.8265 & 2.7745 & 2.8316 & 1.00 & 0.97 & 0.98 & 0.99 \\
\hline 14 & $\mathrm{Bw}_{1}$ & 2.8393 & 2.7628 & 2.7249 & 2.7579 & 0.99 & 0.97 & 0.98 & 0.98 \\
\hline 15 & $\mathrm{C}_{1}$ & 2.8173 & 2.8261 & 2.8101 & 2.7815 & 0.63 & 0.62 & 0.69 & 0.66 \\
\hline 16 & Ap & 2.7711 & 2.7635 & 2.7380 & 2.8117 & 0.89 & 0.89 & 0.90 & 0.88 \\
\hline 17 & Ap & 2.6834 & 2.7128 & 2.6930 & 2.6465 & 0.99 & 0.98 & 0.74 & 0.92 \\
\hline 18 & $\mathrm{Bw}_{2}$ & 2.8582 & 2.8598 & 2.8210 & 2.852 & 0.54 & 0.65 & 0.72 & 0.70 \\
\hline 19 & Ap & 2.6983 & 2.7406 & 2.7997 & 2.6941 & 0.91 & 0.95 & 0.90 & 0.95 \\
\hline 20 & Ap & 2.9245 & 2.9276 & 2.9694 & 2.9208 & 0.98 & 0.88 & 0.60 & 0.95 \\
\hline 21 & A & 2.8987 & 2.8958 & 2.9349 & 2.9052 & 0.95 & 0.85 & 0.82 & 0.81 \\
\hline 22 & $\mathrm{Bw}_{1}$ & 2.8899 & 2.9102 & 2.8775 & 2.893 & 0.68 & 0.65 & 0.74 & 0.65 \\
\hline 23 & A & 2.9022 & 2.887 & 2.8878 & 2.8821 & 0.95 & 0.83 & 0.87 & 0.83 \\
\hline 24 & $\mathrm{Bt}_{1}$ & 2.9018 & 2.9273 & 2.9344 & 2.9125 & 0.61 & 0.66 & 0.50 & 0.59 \\
\hline 25 & Ap & 2.8436 & 2.8505 & 2.8220 & 2.8461 & 0.72 & 0.76 & 0.80 & 0.74 \\
\hline 26 & $\mathrm{~A}$ & 2.8929 & 2.9152 & 2.9067 & 2.916 & 0.95 & 0.90 & 0.95 & 0.78 \\
\hline 27 & $\mathrm{Ap}$ & 2.8214 & 2.8416 & 2.8204 & 2.7746 & 0.69 & 0.75 & 0.8 & 0.78 \\
\hline 28 & A & 2.8806 & 2.9158 & 2.8754 & 2.8879 & 0.68 & 0.64 & 0.79 & 0.70 \\
\hline \multirow[t]{2}{*}{29} & Ap & 2.8917 & 2.9146 & 2.8880 & 2.8932 & 0.67 & 0.59 & 0.71 & 0.61 \\
\hline & Average & 2.8438 & 2.8489 & 2.8343 & 2.8336 & 0.85 & 0.81 & 0.83 & 0.83 \\
\hline
\end{tabular}

\footnotetext{
${ }^{1}$ Ds; fractal for no-pretreatment, Dso; fractal for organic matter removal, Dsc; fractal for $\mathrm{CaCO}_{3}$ removal, Dsoc; $\mathrm{OM}_{\text {and }} \mathrm{CaCO}_{3}$
} removal

calculated after calcium carbonate removal were presented in Tables $2 \& 3$. Kerry and Oliver (2006) stated that calcium carbonate in soil is composed of mainly tiny calcite crystals which dominate the clay-sized fraction. Dispersing the soil during the pipette or hydrometer methods can result in the break-up of sand and silt size calcium carbonate fragments into smaller calcite crystals. In this case, the soil appears more clayey in texture than the soil normally is (Kerry \& Oliver 2006). Dissolution of carbonates with sodium acetate buffer (buffered to $\mathrm{pH} 5$ with acetic acid) would result in decreasing the clay contents as compared to that of measured with organic matter removal and without pretreatments. Whereas, the sand contents obtained after calcium carbonate removal were relatively increased as a results of decreasing the clay content. One may expect the opposite as carbonates often act as a cementing agent to cluster smaller particle into larger units. However, Khodaverdiloo et al (2011) also reported that the sand percentage, and hence also the mean soil particle size, increased after removing $\mathrm{CaCO}_{3}$. Khodaverdiloo et al (2011) 
Table 4-Paired t-tests and correlations ( $r=$ correlation coefficient) for particle size components and fractals calculated ${ }^{1}$

Çizelge 4-Parçacık büyüklüğü bileşenleri ve hesaplanan fraktal değerleri için eşleştirilmiş t-testleri ve korelasyonlar ( $r=$ korelasyon katsayısi)

\begin{tabular}{|c|c|c|c|c|c|c|c|c|}
\hline $\begin{array}{l}\text { Pairs } \\
N=29\end{array}$ & $\begin{array}{l}D_{s} \text {-Mean } \\
\text { difference }\end{array}$ & $r$ & $\begin{array}{l}\text { Sand-Mean } \\
\text { difference }\end{array}$ & $r$ & $\begin{array}{l}\text { Clay-Mean } \\
\text { difference }\end{array}$ & $r$ & $\begin{array}{l}\text { Silt-Mean } \\
\text { difference }\end{array}$ & $r$ \\
\hline NP-O & $-0.012(0.009)$ & $0.95(0.000)$ & $0.750(0.563)$ & $0.95(0.000)$ & $-2.249(0.040)$ & $0.96(0.000)$ & $1.468(0.323)$ & $0.79(0.000)$ \\
\hline NP-C & $0.024(0.091)$ & $0.70(0.003)$ & $-3.233(0.048)$ & $0.89(0.000)$ & $0.762(0.677)$ & $0.94(0.000)$ & $2.473(0.086)$ & $0.80(0.000)$ \\
\hline NP- OC & $0.007(0.164)$ & $0.95(0.000)$ & $-1.824(0.219)$ & $0.94(0.000)$ & $0.805(0.506)$ & $0.96(0.000)$ & $1.022(0.407)$ & $0.86(0.000)$ \\
\hline $\mathrm{O}-\mathrm{C}$ & $0.036(0.019)$ & $0.66(0.000)$ & $-3.983(0.000)$ & $0.92(0.000)$ & $3.010(0.060)$ & $0.98(0.000)$ & $1.005(0.319)$ & $0.91(0.000)$ \\
\hline $\mathrm{O}-\mathrm{OC}$ & $0.019(0.000)$ & $0.96(0.000)$ & $-2.574(0.000)$ & $0.97(0.000)$ & $3.054(0.001)$ & $0.99(0.000)$ & $-0.446(0.600)$ & $0.93(0.000)$ \\
\hline $\mathrm{C}-\mathrm{OC}$ & $-0.017(0.253)$ & $0.67(0.000)$ & $1.409(0.081)$ & $0.93(0.000)$ & $0.044(0.976)$ & $0.98(0.000)$ & $-1.451(0.118)$ & $0.92(0.000)$ \\
\hline
\end{tabular}

further pointed out that determination of soil water retention of acid-treated soil samples or removal of $\mathrm{CaCO}_{3}$ may lead to unrealistic results when used for field water management, or for agricultural or environmental modeling applications. The phenomenon was also stated in (Soil Survey Staff 2010) as "calcium carbonate particles within the clay size did not act as clay particles to retain soil water".

Since the clay content decreased, the lowest $\mathrm{D}_{\mathrm{sc}}$ was also obtained after removal of carbonates (Table 3). The $\mathrm{D}_{\mathrm{sc}}$ values and sand contents after calcium carbonate removal were significantly different from those of non pretreated samples $(P<0.01$ and 0.05 respectively). It is clear that organic matter oxidation enhances the clay content whereas calcium carbonate dissolution decreases clay contents of soils. Therefore, the $\mathrm{D}_{\mathrm{sc}}$ values $(P<0.05)$ and sand contents $(P<0.01)$ obtained after organic matter removal and calcium carbonate removal were significantly different, but not clay content $(P=0.06)$.

A second degree polynomial regression equation successfully described the relationship between fractal dimension and clay content obtained after calcium carbonate dissolution (Figure 2). The gradually decreasing slope describes the relationship between $D_{s}$ and clay content of the soils. The results indicate a decreasing rate of contribution from fine particles to the extent of $\mathrm{D}_{\mathrm{s}}$ (Figure 2). Ersahin et al (2006) also reported that a second degree polynomial regression equation described the relationship between fractal dimension and clay content. Tyler and Wheatcraft (1992) found $\mathrm{D}_{\mathrm{s}}$ values getting closer to 3.0 associated with the finest textured soils.

\subsection{Effect of organic matter together with calcium carbonate}

The sand, clay and silt contents and $\mathrm{D}_{\text {sco }}$ values of soil samples obtained after organic matter removal plus calcium carbonate dissolution were not significantly different from those obtained for untreated soil samples. The distribution of soils within the soil texture triangle was also quite similar to the distribution obtained for untreated soils (Figure 1). Although small differences were occurred with the values, strong correlations were found between treated and non treated samples $(r=0.941,0.956,0.863$ and 0.946 , respectively). However, sand and clay contents were significantly different from those obtained after single organic matter removal process (Table 4). Carbonate removal probably caused the preferential removal of carbonate particles within the clay size. Therefore, mean clay content 
obtained only with organic matter removal was $44.61 \%$ and decreased to $41.55 \%$ after organic matter plus calcium carbonate removal.

The relationship between clay content and fractal dimension for organic matter removal plus calcium carbonate dissolution was also described with a second degree polynomial regression equation. The shape of the curve indicated that the relationship tends to be increased more for the first increases in clay content than the later increases (Figure 2).

Soil samples were divided into two sub-classes based clay contents to evaluate the extent of pretreatments effects on particle size distributions and fractal dimensions. The first group soils were representing those located out of the clay in textural triangle and the second group soils were located within the clay class in textural triangle. Clay contents in the first group $(\mathrm{N}=14)$ ranged from $12.5 \%$ to $43.1 \%$, and in the second group $(\mathrm{N}=15)$ ranged from $43.5 \%$ to $66.5 \%$.

The mean fractal dimensions for different pretreatments were ranged from 2.7562 to 2.7952 for the first clay content group and from 2.8890 to 2.9102 for the second clay content group. The highest Ds value obtained with organic matter removal and the lowest Ds was with $\mathrm{CaCO}_{3}$ dissolution in both clay content ranges evaluated. The effect of pretreatments on Ds values in both clay ranges was similar to those obtained for the complete set of soils (Table 5).

The organic matter removal significantly affected the mean fractal dimension, sand content and clay content of the second group of soils however; it did not affect any of the particle size distribution and fractal dimension of the first group. Results indicated that organic matter removal is more effective in the soils classified within the clay group then the rest of the soils (Table 6).

On the other hand, dissolution of calcium carbonate resulted in significant differences in the fractal dimension, sand and silt contents for the first group of soils. Whereas, the effect of calcium carbonate dissolution in the second group soils was not as effective as in the first group of soils. In general, paired t-test results of the pretreatments revealed that pretreatments used alone or combination except organic matter removal alone are more effective in fragmentation in the lower clay content ranged indicated as the first group of soils.

\section{Conclusions}

The effect of removing organic matter and calcium carbonate dissolution of soils, which are different in pedogenesis (Entisols, Inceptisols, Mollisols, Alfisols and Vertisols), calcium carbonate (5.57-60.09\%), organic matter $(0.05 \%$ $4.25 \%)$ and clay content $(12.5 \%-66.5 \%)$ on particle size distributions and fractal dimensions were investigated. Results revealed that organic matter removal enhances the aggregate fragmentation and increases clay contents of soils. The fractal dimensions occurred after organic matter removal were higher as compared to the Ds obtained for the calcium carbonate removal. Since the pedogenic carbonates in the soils are composed of fine calcite crystal sizes, particle size distributions obtained without any pretreatments

Table 5-Descriptive statistics of subdivision of soil samples based on clay contents Çizelge 5-Kil içeriğine göre alt gruplara ayrılan toprak örneklerinin tanımlayıcı istatistikleri

\begin{tabular}{cccc|ccc}
\hline & \multicolumn{3}{c|}{ Clay Content $12.5 \%-43.1 \%$} & \multicolumn{3}{c}{ Clay Content 43.5\%-66.5\% } \\
\hline Ds & Minimum & Maximum & Mean & Minimum & Maximum & Mean \\
\hline NP & 2.6783 & 2.8546 & 2.7843 & 2.8616 & 2.9288 & 2.8971 \\
O & 2.7132 & 2.8658 & 2.7952 & 2.8620 & 2.9420 & 2.9102 \\
C & 2.6453 & 2.8494 & 2.7562 & 2.6930 & 2.9773 & 2.8890 \\
OC & 2.6653 & 2.8448 & 2.7628 & 2.8555 & 2.9303 & 2.9039 \\
\hline
\end{tabular}

NP; no-pretreatment, $\mathrm{O}$; removal of organic matter, $\mathrm{C}$; removal of $\mathrm{CaCO}_{3}$, $\mathrm{OC}$; removal of organic matter and $\mathrm{CaCO}_{3}$ 
Table 6-Paired t-tests of particle size components and fractals calculated for the subdivisions based on clay content ${ }^{1}$

Çizelge 6-Kil içeriğine göre alt grupların parçacık büyüklük bileşenleri ve fraktal değerlerinin eşleştirilmiş t-testleri

\begin{tabular}{|c|c|c|c|c|c|c|c|}
\hline & Pairs & $\begin{array}{c}\text { D-Mean } \\
\text { difference }\end{array}$ & $r$ & $\begin{array}{c}\text { Sand-Mean } \\
\text { difference }\end{array}$ & $r$ & $\begin{array}{l}\text { Clay-Mean } \\
\text { difference }\end{array}$ & $r$ \\
\hline \multirow{6}{*}{$\begin{array}{l}\text { Clay content } \\
12.5 \%-43.1 \%\end{array}$} & NP-O & $-0.011(0.186)$ & $0.87(0.000)$ & $-3.45(0.111)$ & $0.93(0.000)$ & $-0.38(0.715)$ & $0.91(0.000)$ \\
\hline & NP-C & $0.028(0.017)$ & $0.77(0.001)$ & $-8.06(0.002)$ & $0.93(0.000)$ & $4.53(0.004)$ & $0.85(0.000)$ \\
\hline & NP-OC & $0.022(0.020)$ & $0.86(0.000)$ & $-6.68(0.009)$ & $0.92(0.000)$ & $3.86(0.016)$ & $0.82(0.000)$ \\
\hline & $\mathrm{O}-\mathrm{C}$ & $-0.039(0.000)$ & $0.89(0.000)$ & $-4.61(0.000)$ & $0.99(0.000)$ & $-4.91(0.000)$ & $0.95(0.000)$ \\
\hline & $\mathrm{O}-\mathrm{OC}$ & $0.032(0.001)$ & $0.85(0.000)$ & $-3.23(0.000)$ & $0.99(0.000)$ & $4.24(0.003)$ & $0.87(0.000)$ \\
\hline & $\mathrm{C}-\mathrm{OC}$ & $-0.007(0.485)$ & $0.82(0.000)$ & $1.38(0.018)$ & $0.99(0.000)$ & $0.67(0.611)$ & $0.85(0.000)$ \\
\hline \multirow{6}{*}{$\begin{array}{l}\text { Clay content } \\
43.5 \%-66.5 \%\end{array}$} & NP-O & $-0.013(0.004)$ & $0.85(0.000)$ & $4.95(0.000)$ & $0.96(0.000)$ & $-4.12(0.033)$ & $0.77(0.001)$ \\
\hline & NP-C & $0.008(0.595)$ & $0.57(0.028)$ & $1.59(0.339)$ & $0.45(0.096)$ & $-3.00(0.353)$ & $0.53(0.045)$ \\
\hline & NP-OC & $0.007(0.082)$ & $0.82(0.000)$ & $3.03(0.001)$ & $0.88(0.000)$ & $-2.25(0.186)$ & $0.72(0.003)$ \\
\hline & $\mathrm{O}-\mathrm{C}$ & $0.021(0.238)$ & $0.23(0.414)$ & $-3.36(0.046)$ & $0.54(0.036)$ & $-1.12(0.710)$ & $0.61(0.015)$ \\
\hline & $\mathrm{O}-\mathrm{OC}$ & $0.006(0.036)$ & $0.93(0.000)$ & $-1.92(0.020)$ & $0.88(0.000)$ & $1.87(0.128)$ & $0.69(0.040)$ \\
\hline & $\mathrm{C}-\mathrm{OC}$ & $-0.015(0.369)$ & $0.38(0.162)$ & $1.44(0.353)$ & $0.58(0.023)$ & $-0.76(0.782)$ & $0.91(0.000)$ \\
\hline
\end{tabular}

overestimate the clay content of soils. The nature of fine calcite crystals do not resemble to clay particles, therefore if the soil contains $\mathrm{CaCO}_{3}$, particle size distributions should be determined after $\mathrm{CaCO}_{3}$ dissolution. Since the behavior of carbonates within the clay size from water holding point of view is similar to the silt fraction, removing the clay size carbonates results in obtaining unrealistic results particularly for determination of soil water retention. Therefore, carbonates should not be removed if water holding capacity of soils are going be used for field water management, or for agricultural or environmental modeling applications. The combined effects of increasing clay content with organic matter removal due to the better fragmentation and dissolution of clay sized calcite crystals after $\mathrm{NaOAc}$ pretreatments resulted in similar particle size distributions and fractal dimension values to those obtained for non pretreated samples.

\section{References}

Bittelli M, Campbell G S \& Flury M (1999). Characterization of particle-size distribution in soils with a fragmentation model. Soil Science Society of American Journal 63:782-788

Bronick C J \& Lal R (2005). Soil structure and management: A review. Geoderma 124:3-22

Ersahin S, Gunal H, Yetgin B, Kutlu T \& Coban S (2006). Estimating specific surface area and cation exchange capacity in soils with fractal dimension of particle-size distribution. Geoderma 136(3,4): 588597

Eshel G, Levy J, Mingelgrin U \& Singer M J (2004). Critical evaluation of the use of laser diffraction for particle-size distribution analysis. Soil Science Society of American Journal 68:736-743

Feller C, Schouller E, Thomas F, Rouiller J \& Herbillon A J (1992). $\mathrm{N}_{2}$-BET specific surface areas of some 
low activity clay soils and their relationships with secondary constituents and organic matter contents. Soil Science 153:293-299

Filgueira R R, Pachepsky Y A \& Fournier L L (2003). Time-mass scaling in soil texture analysis. Soil Science Society of American Journal 67(6):17031706

Filgueira, R R, Fournier L L, Cerisola C I, Gelati P \& Garcia M G (2006). Particle-size distribution in soils: a critical study of the fractal model validation. Geoderma 134:327-334

Gee G W \& Bauder J W (1986). Particle size analysis. In: Methods of Soil Analysis. A. Klute (Ed), Part 1, $2^{\text {nd }}$ ed. Agronomy No. 9. American Society of Agronomy, Madison, WI, pp. 825-844

Hesse P R (1976). Particle size distribution in gypsic soils. Plant and Soil 44:241-247

Jin Z, Dong Y S, Qi Y C, Liu W G \& An Z S (2011). Characterizing variations in soil particle size distribution along a grass-desert shrub transition in the ordos plateau of inner Mongolia, China. Land Degradation and Development. DOI: 10.1002/ldr.1112

Kerry R \& Oliver M A (2006). How should soil texture be determined for chalk soil? 18th World Congress of Soil Science. July 5-9, 2006. Philadelphia, PA, USA

Khodaverdiloo H, Homaee M, van Genuchten M T \& Dashtaki S G (2011) Deriving and validating pedotransfer functions for some calcareous soils. Journal of Hydrology 399:93-99

Kleinbaum D G, Kupper L L \& Muller K E (1988). Applied Regression Analysis and Other Multivariable Methods. Second Edition, Duxbury Press. Belmont, CA. USA

Leifeld J \& Kögel-Knabner I (2003). Microaggregates in agricultural soils and their size distribution determined by X-ray attenuation. European Journal of Soil Science 54:167-174

Nelson D W \& Sommers L E (1982). Total carbon, organic carbon, and organic matter. In: Methods of Soil Analysis. Page, A.L. (Ed) Part 2, $2^{\text {nd }}$ ed. Agron. Monogr. 9. ASA. And SSSA, Madison, WI, pp. 539-579

Perfect E \& Kay B D (1991). Fractal theory applied to soil aggregation. Soil Science Society of American Journal 55:1552-1558

Posadas A N D, Gimenez D, Bittelli M, Vaz C M P \& Flury M (2001), Multifractal characterization of soil particle-size distributions. Soil Science Society of
American Journal 65:1361-1367

Rasiah V, Kay B D \& Perfect E (1993), New massbased model for estimating fractal dimensions of soil aggregates. Soil Science Society of American Journal 57:891-895

Schmidt M W I, Rumpel C \& Koegel-Knabner I (1999). Particle size fractionation of soil containing coal and combusted particles. European Journal of Soil Science 50:515-522

Schultz M K, Biegalski S R, Inn K G W, Yu L, Burnett W C, Thomas L J W \& Smith G E (1999). Optimizing the removal of carbon phases in soils and sediments for sequential chemical extractions by coulometry. Journal of Environmental Monitoring 1:183-190

Soil Survey Division Staff (1993). Soil Survey Division Staff. 1993. Soil Survey Manual. USDA Handbook 18. United States Government Print Office, Washington, DC. USA

Soil Survey Staff (2010). Keys to Soil Taxonomy. 11th ed., USDA National Resources Conservation Service, Washington, DC. USA http://soils.usda.gov/technical/ classification/tax_keys/

Stanchi S E, Bonifacio E Z \& Perfect E (2008). Chemical and physical treatment effects on aggregate breakup in the 0- to 2-mm size range. Soil Science Society of American Journal 72(5):14181421

Stanchi S, Bonifacio E Z \& Pachepsky E Y (2006). Fractal behavior in particle-size distributions as influenced by soil properties and determination method. Soil Science 171(4):283-292

Tisdall JM (1996). Formation of soil aggregates and accumulation of soil organic matter. In: Carter, MR., Stewart, B.A. (Eds.), Structure and Organic Matter Storage in Agricultural Soils. Lewis Publishers, Boca Raton, FL, pp. 57-96

Tyler S W \& Wheatcraft S W (1992). Fractal scaling of soil-particle size distributions: Analysis and Limitations. Soil Science Society of American Journal 56:362-369

Wilding L P, \& Dress L R (1983). Spatial variability in pedology In L.P. Wilding et al. (ed). Pedogenesis and soil taxonomy. I: concepts and interactions. Elseveir, New York, p. 83-116

Wu Q, M Borkovec, \& Sticher H (1993). On particlesize distribution in soils. Soil Science Society of American Journal 57:883-890 